\title{
ELT Materials Evaluation: A System and Criteria
}

\author{
Ali Işik \\ Istinye University, Istanbul, Turkey
}

\begin{abstract}
This study aims at proposing a 3-stage materials evaluation system and separate checklists for screening and detailed analysis and testing their effectiveness. The checklists were developed at two stages: First they were developed by 113 trainees as the requirement of the materials evaluation training program and evaluated by 43 ELT teachers. Later both the system and the checklists themselves were piloted and tested in real-life by 11 ELT teachers when adopting ELT materials for their students. The data was collected through 5-point Likert scale questionnaires. The results indicated that the system allows for the quick disqualification of the inappropriate ones and saves enough time to focus on the candidate ones in detail. The checklists themselves are found to be both reliable and valid.
\end{abstract}

Index Terms-ELT materials, materials evaluation checklists, language education

\section{INTRODUCTION}

ELT materials establish the backbone for English language education (Tomlinson \& Masuhara, 2017). Generally speaking in many language programs they function as the de facto syllabus and dictate what to teach, in what order to teach, even the density and pace of teaching (AbdelWahab, 2013; Allen, 2015; Garton, \& Graves, 2014; Mishan \& Timmis, 2015). Thus, they provide a common ground for both learners and teachers in an institution and besides determining the content they also control what to and how to teach and test. Not only do they regulate content but also how to implement and realize language education (Harwood, 2014; McGrath, 2013). Each ELT material is based on a language teaching philosophy (approach) which guides how to realize its principles in actual use via materials (Richards, 2006). In other words, ELT materials are more than content, they impose a teaching methodology on both teachers and learners ( Hart, 2003; Iș1k, 2011, 2013a, 2013b, 2018; Tomlinson, 2010). When they are adopted, language teaching methodology get adopted together with them, too. It is highly likely to say that the degree to which the methodology is in congruence with the overall goal of a language program, decides the success of a language education program (Harwood, 2010). Likewise, they are of a great help for especially novice teachers (Garton \& Graves, 2014; LópezMedina, 2016). If they are based on a sound methodology, they are likely to guide and scaffold teachers to be efficient teachers. The tasks and teaching tips help them get to be equipped with the knowledge and skills to be self-sufficient, even maybe, exploratory teachers. They also orient learners about how to learn a second/foreign language through the tasks they provide. Even some ELT materials have specific tasks on language learning strategies to train learners to become successful learners. Furthermore, they are the main source of language input for learners. Nowadays learners can have access to ample amount of input on the internet (Allehyani, Burnapp \& Wilson, 2017) however, being exposed to the relevant materials at the appropriate level of cognitive and linguistic difficulty is a problem. The ELT materials, in that sense, ensures to provide learners with the appropriate materials. ELT materials are accompanied by the periphery; audios, videos, workbooks, assessment packs, projects packs, I-tools, etc. which all create a variety of texts and tasks and enrich languages activities both in and out of the classroom. This variety also helps to address different needs and interests and individualize activities especially outside the class. I-tool applications engage students and facilitate comprehension of the texts and tasks. Together with the I-tools, online applications take learners beyond the boundaries of schools and integrate them with the rest of the world (Allen, 2015; Kukulska-Hulme, Norris \& Donohue, 2015). Moreover, they pave the way for creating a global community in which learners get engaged in real, authentic interaction with others. Some materials, in addition, are conducive for self-regulated learning. They create online platforms for both teachers and learners by which teachers follow what activities their students do, how much time they spend doing those and how successful they are in task completion. The same feedback is also given to learners themselves. Those platforms also provide progress checks at the defined intervals. Both the activity reports and progress checks provide invaluable feedback to teachers and learners to diagnose their weaknesses and strengths and behave accordingly (Tomlinson \& Masuhara, 2017). To sum up, ELT materials are essential for any language education programs and they set the ground for the language teaching/learning process (McGrath; 2006, 2016; Tomlinson, 2008).

The effort to emphasize the pivotal role of materials evaluation has abounded (Tomlinson, 2013). It has aimed to guide the stake holders to consider it a data-driven, disciplined and informed decision-making process. The pioneers in the field not only set the theoretical ground but also carried out research and came up with practical implications, even with materials evaluation checklists (Brown, 1995; Cunningsworth, 1995; Dubin, \& Olshtain, 1986; Ellis, 1997; Graves, 1996, 2000; Grossman, \& Thompson, 2008; Guyer, \& Peterson, 1988; Hargreaves,1989;Harmer, 2003, Hirsch, 1988; Hutchinson\& Waters, 1987; Johnson, 1989; Krahnke, 1987; Letter, 2000; Littlejohn \& Windeatt,1989; McDonough \& Shaw, 1993; McGrath, 2002; O’Neill,1982; Purgoson, 1991; Richard-Amato, 1988; Sheldon, 1987; Skierso, 1991; 
Tomlinson, 2003; Willis, 2000). The theoretical and practical knowledge and data about materials have been accumulated and raised the awareness of stake holders about the issue. That knowledge has spread out and contributed to make the materials evaluation a global concern (McGrath, 2016; McDonough, et al., 2013; Tomlinson \& Masuhara, 2017). In turn the research on it has also flourished globally and researchers all around the world have contributed to the ever-growing body of knowledge in the field (Garton \& Graves, 2014). That concern even gave birth to the birth of a professional association, The Materials Development Association (MATSDA) which has offered courses, organized conferences, and provide services. The knowledge accumulated in the field, however, needed to be streamlined and put into practice to meet local needs.

As the knowledge about materials evaluation has developed and evolved, so has materials development (Garton \& Graves, 2014; McGrath, 2016). ELT materials are either developed locally or adopted from among the ones which are on the market developed by the international publishers. The ideal one is developing materials unique for each program; custom-made ones arise from the needs analysis and context analysis to realize the goal(s) of a particular language education program. However, it is a huge task requiring expertise, time, energy, money, and team work. Since materials development is to be a data-driven, disciplined and systematic process, setting the goal(s) of a program, carrying out need and context analysis, preparing interim goals, objectives, determining content and related tasks and following the necessary steps to develop materials, first of all, necessitate expertise (McGrath, 2006; 2016). Materials developers are to be equipped with required knowledge and skills about the materials development and language teaching. It is a demanding task a single person cannot handle, thus, it requires a team. Moreover, they are needed to be accompanied by a team of experts, psychologists, applied linguists, pedagogues, information technology specialists, designers, script writers, directors, etc. All these obviously call for a budget. In short, it is a long process which is time, money and energy consuming and much above the shoulder of a teacher. The logical one is to adopt ELT materials and adapt them for the context in which they are implemented. The adopting process is not an easy one, it necessitates a data-driven, disciplined decision making. Teachers are to collect data through needs and context analysis and then implement evaluation criteria to choose the most appropriate materials (Kostka \& Bunning, 2016). Since the ELT materials developed by publishers, especially international ones, are developed for a broad spectrum of learners, comprehensive, well-designed criteria get in action to choose the best. Evaluation criteria need to be customized as well to serve the specific needs of specific contexts. Obviously, evaluation criteria include items of global use as well as local one; in other words, the criteria must be customized for local use

In Turkey, as in other countries in the world, English is the key for a job, promotion, more income, and pursuing an academic career. There is an English fever (Krashen, 2006) and a great demand to master English. In formal education, the English education starts at the kindergarten and continues at the tertiary level. Besides, there are plenty of private institutions offering English courses. In short, huge amount of time, money, and energy is spent on English, thus, learners are to be provided with appropriate materials. Naturally it can be provided with a sound evaluation process. To make sound, informed, disciplined decisions there is a need for both comprehensive evaluation criteria and a systematic approach for materials evaluation. An approach to evaluate the materials are important because there are plenty of ELT materials in the market and it is impossible to evaluate all the possible materials in detail. To be practical the candidate materials are needed to be screened from among the possible ones and evaluated in detail.

To the knowledge of the researcher, there are only few studies on proposing ELT materials evaluation checklists and testing their efficiency in the new millennium. Reinders \& Lewis (2006), Angell, et al. (2008), Shave (2010), Iş1k \& Atmışdört (2010) and AbdelWahab (2013), López-Medina (2016) developed ELT materials evaluation checklists. Reinders \& Lewis (2006) developed a checklist to evaluate self-access materials and López-Medina (2016) for content language integrated learning (CLIL). Only Işık \& Atmışdört (2010) and AbdelWahab (2013) both developed checklists and tested their effectiveness. Moreover, none of them included a part on "software evaluation" yet it is accompanied by almost any ELT materials. There is definitely a need for a comprehensive checklist as well. In addition, its validity and reliability must be verified and data about its real-life use is to be provided. To sum up, the literature review has indicated the pivotal role of materials evaluation to come up with the most effective ones for each context. Although materials evaluation has aroused global concern, the research on materials evaluation checklists and proposing new checklists is not so common. Besides, since each context is unique it is mandatory to customize the evaluation process for each specific context. Moreover, the proposed checklists are no different from one another and a systematic approach to the ELT materials evaluation process has not been offered to make it more efficient and save time to focus more on the possible candidate ELT materials. In short, this study aims at proposing a 3-stage ELT materials evaluation system to create an efficient evaluation process and suggest detailed comprehensive checklists that can be exploited while forming ones for each specific ELT context.

\section{Methodology}

\section{A. Aim}

The aim of the study is to develop comprehensive materials evaluation checklist in a two-stage fashion and to test its effectiveness.

\section{B. References}


Three groups of subjects participated in the study. The first group consisting of 113 trainees prepared the items for the criteria. The second group consisting of 43 English teachers tested the effectiveness of the items in the criteria. The third group, 11 teachers piloted the checklists.

\section{Treatment}

A 12-week training program was designed for the trainees who met three hours a week (see Appendix 1). In the first three weeks they study the articles on ELT materials to have a general perspective about the topic. The following three weeks they focused on materials evaluation and examined checklists. Each week, the trainer divided the class in groups and each group raised a real-life issue about topics of the week and offered solutions for them. In the 7th and 8th weeks they worked in groups to develop their own checklists. The trainer functioned as a member of each group and provided continuous feedback. At the end of the 8th week the groups shared their checklists with the others online and came to class evaluating them in the 9th week. In that week each group presented their checklists to the class and first other trainees (classmates) and then the trainer gave feedback about them. Upon receiving the feedback the group revised their checklists during the week after the class. In the 10th week in the class, the same groups started to evaluate the ELT materials used in their schools. The trainer again worked with each group. The process continued in the 11th week. At the end of the week, each group posted their evaluation to the whole class to get feedback about their evaluation. In the 12th week each group presented their evaluations and received feedback from their friends and teachers. Based on the feedback they received, they were required to revise their projects and submit them to the trainer within two weeks. The training program lasted two years with the participation of different trainees.

\section{The Materials Evaluation System}

A three-stage materials evaluation process is adopted; screening stage and a thorough detailed analysis stage. There are numerous ELT materials on the market it is too time- and energy consuming to evaluate each book in detail. The two-stage evaluation helps to ease the burden. In first stage "the quick evaluation checklist" is employed to screen the books to determine the candidate ELT materials for furher detailed analysis. In other words, this stage eliminates the unqualified ones and delimits the number of ELT materials to be evaluated in the second stage. The evaluation approach is unique in a sense that it spares enough time to focus on the candidate books in detail in the second stage. The screening (quick evaluation) checklist is employed in the first, detailed evaluation checklist is used in the second stage.

\section{E. The Item Development Process}

The aim is to come up with two checklists, one for the screening to determine the candidate materials, and a comprehensive one for further detailed evaluation. The subjects started to work with a trainer who has evaluated, adapted, and developed materials, worked as a freelance materials evaluator for international publishers since 1989, and offered courses on ELT materials since 1999. After discussing the materials in the course pack in order to form the theoretical basis of materials evaluation, the trainees grouped in the groups of three or four. Each group was required to come up with two sets of items one for the quick evaluation checklist one for the comprehensive one. The tasks were carried out both in and out of the classroom and the trainer acted as a member of each group and provided feedback when necessary on the spot. The groups worked on their checklists for two weeks and revised them. Finally, they submitted their checklist to the trainer. The trainer worked on each checklist and created one checklist for screening (quick evaluation) and one for comprehensive detailed evaluation composed of different subcategories such as external evaluation, internal evaluation, face validity, approach, teacher-related factors, etc.

After the trainer had come with the checklists, judgmental evaluation was carried out by 43 English teachers who evaluated the quality of each item in the checklists using a 5 Likert scale. With an open-ended item in the questionnaire they are also asked what other items they would add to the checklist. In addition, to elicit their ideas about the general evaluation of the checklist another questionnaire was administered to the teachers. Depending on the feedback from the teachers, the reliability and validity of the checklists was carried out item by item. Some items were deleted, revised and added in the checklists. They were revised considering the feedback and suggestions given by the teachers and they were finalized. In other words, they got ready for piloting- the actual use (see Appendix 2).

During the judgmental evaluation teachers also answered the open-ended item. One teacher indicated that the deliberate focus on target language culture had to be looked for in materials evaluation. In the same vein, three teachers demanded native speaker standards in pronunciation. Since English as a Lingua Franca (ELF) approach has been widely adopted and it is hard to determine which target culture and dialect (American, British, Australian, etc.) are to be taught, that suggestion was realized in the item related with ELF. Two teachers suggested and item about the size of the coursebooks and offered A4 size so that they could fit in a student school bag. It was thought about and decided that size is important and that suggestion was revised and added in the checklist. One teacher offered a hardcover-related item. Since hardcover might add extra cost for the materials and it is unlikely to find hardcover ones on the market, that suggestion was disqualified. One teacher offered that materials should have an extra booklet in which the parts in the materials students are required to write would be transferred there and student materials could be kept clean and used again and again. As providing compact materials is more convenient, that suggestion was not put into practice while developing the checklist.

\section{F. Data Collection and Data Analysis}


Use The data were collected at two stages, initial evaluation and piloting. The first step was judgmental and the second practical. The first stage was carried out with 43 teachers to learn their ideas about the checklists and the approach. The second stage was actually a real-life one as it was implemented to choose course materials by eleven teachers. The teachers were supposed to adopt new course materials for the following academic year and they exploited the approach and the checklists. For both stages the evaluation criteria were given to the teachers and the data was collected through a five-point Likert. SPSS was used to analyze the data.

\section{G. Validity of the Questionnaires}

The use of an expert panel to provide critical feedback served to facilitate the development and refinement of the checklist application in the second investigation. In addition, the expert panel was considered an integral design element to demonstrate content relevance and representativeness along with the substantive and consequential aspects of validity.

\section{H. Reliability of the Questionnaires}

Internal consistency of the survey instrument was estimated by using Cronbach's coefficient alpha. In this particular study, coefficient alpha ranged from .78 to.79, suggesting a high estimate of reliability based on the mean inter-item correlation.

\section{RESULTS}

First trainees were asked to evaluate the training program and the results are as follows.

None of the trainees indicated any options but "highly satisfactory". With no exception all the trainees marked the "highly satisfactory" option.

TABLE I

The Results Of The Survey On The Training Program

\begin{tabular}{|l|l|l|l|l|l|}
\hline & Highly unsatisfactory & Unsatisfactory & Neutral & Satisfactory & Highly satisfactory \\
\hline Ideas about the training & & & & & $100 \%$ \\
\hline
\end{tabular}

The data about the checklists were collected at two different stages, judgmental evaluation and practical (piloting) evaluation.

\section{A. Judgmental Evaluation}

The results obtained from the teachers who evaluated the effectiveness of the checklist are summarized in the tables below:

Screening: Table 2 summarizes how teachers evaluated the screening checklist.

TABLE II

RESUlTS OF THE SCREENING

\begin{tabular}{|l|l|l|l|l|l|}
\multicolumn{7}{c}{ RESULTS OF THE SCREENING } \\
\hline & Mean & Min. & Max. & Var. & Cronbach Alpha \\
\hline Screening & 3.98 & 3.51 & 4.09 & 0,02 & 0,93 \\
\hline
\end{tabular}

The reliability for the screening component of the proposed system is found to be within the acceptable range.

\section{B. Detailed Evaluation}

The results of the detailed evaluation are presented in two subcategories, external evaluation and internal evaluation.

\section{External Evaluation}

In Table 3 the external evaluation subcategory results indicate that teachers found it effective. The Cronbach Alpha values about each external evaluation subcategory are also very high, the reliability of this subcategory is quite high.

TABLE III

THE PROPOSED SySTEM EVALUATION RESUlTS

\begin{tabular}{|l|l|l|l|l|l|}
\hline & Highly unsatisfactory & Unsatisfactory & Neutral & Satisfactory & Highly satisfactory \\
\hline It is practical & & $3 \%$ & $12 \%$ & $42 \%$ & $43 \%$ \\
\hline It is effective & & & & $49 \%$ & $51 \%$ \\
\hline It is time-saving & & & $6 \%$ & $43 \%$ & $51 \%$ \\
\hline
\end{tabular}

\section{Internal Evaluation}

Table 4 indicates that the detailed internal evaluation part is found to be effective by the teachers. The reliability values of the subcategories of internal evaluation are within the acceptable range. 
TABLE IV

RESULTS OF THE INTERNAL EVALUATION

\begin{tabular}{|l|l|l|l|l|l|}
\hline & Mean & Min. & Max. & Var. & Cronbach Alpha \\
\hline Aim & 3.86 & 3.23 & 4.31 & 0.95 & 0.89 \\
\hline Approach & 3.13 & 2.92 & 3.47 & 0.03 & 0.91 \\
\hline Syllabus & 3.63 & 3.17 & 4.12 & 0.08 & 0.83 \\
\hline Linguistic Aspect & 3.93 & 3.76 & 4.39 & 0.15 & 0.91 \\
\hline Teacher-related Factors & 3.76 & 3.39 & 3.10 & 0.04 & 0.93 \\
\hline Student-related Factors & 3.50 & 3.03 & 4.06 & 0.08 & 0.91 \\
\hline Classroom Organization & 3.77 & 3.41 & 4.04 & 0.05 & 0.96 \\
\hline Instructions & 4.09 & 2.93 & 3.23 & 0.02 & 0.93 \\
\hline Content & 3.69 & 2.79 & 3.56 & 0.16 & 0.96 \\
\hline Culture & 3.60 & 2.71 & 4.36 & 0.03 & 0.89 \\
\hline Lexis & 3.89 & 3.37 & 4.43 & 0.09 & 0.91 \\
\hline Skills & 3.15 & 2.95 & 3.65 & 0.03 & 0.87 \\
\hline Unit Format & 3.57 & 3.23 & 4.12 & 0.07 & 0.86 \\
\hline Measurement and Evaluation & 4.10 & 3.87 & 4.56 & 0.19 & 0.84 \\
\hline Software & 3.77 & 3.56 & 4.09 & 005 & 00.93 \\
\hline
\end{tabular}

\section{E. The Overall Evaluation}

The teachers are asked to evaluate the materials evaluation system (screening and detailed evaluation) in general. The results are as follows:

TABLE V

OVERALL EVALUATION RESULTS

\begin{tabular}{|l|l|l|l|l|l|}
\hline & Highly unsatisfactory & Unsatisfactory & Neutral & Satisfactory & Highly satisfactory \\
\hline It is practical & & & $6 \%$ & $46 \%$ & $48 \%$ \\
\hline It is effective & & & & $58 \%$ & $42 \%$ \\
\hline It is time-saving & & $3 \%$ & $9 \%$ & $52 \%$ & $36 \%$ \\
\hline
\end{tabular}

\section{F. Practical Evaluation (Piloting) Results}

Table 6 presents the results of piloting. It indicates a high reliability of the checklist in general:

TABLE VI

PRACTICAL EVALUATION RESULTS

\begin{tabular}{|l|l|}
\hline & Cronbach Alpha \\
\hline Screening & 0.93 \\
\hline External evalaution & 0.87 \\
\hline Internal evalauation & 0.89 \\
\hline
\end{tabular}

\section{G. Evaluation of the Proposed System}

The teacher who piloted the checklists during their materials adaptation process were also asked given the questionnaire to elicit their overall all impression about the materials evaluation approach. Table 7 summarizes the results.

TABLE VII

THE Proposed System EVALUATION RESUlTS

\begin{tabular}{|l|l|l|l|l|l|}
\hline & Highly unsatisfactory & Unsatisfactory & Neutral & Satisfactory & Highly satisfactory \\
\hline It is practical & & $3 \%$ & $12 \%$ & $42 \%$ & $43 \%$ \\
\hline It is effective & & & & $49 \%$ & $51 \%$ \\
\hline It is time-saving & & & $6 \%$ & $43 \%$ & $51 \%$ \\
\hline
\end{tabular}

\section{Discussion}

Trainees seem to be satisfied with the content of the training and the tasks they carried out. Since ELT materials are vital in the language process, participating in such a training and fulfilling relevant tasks fostered their involvement.

The data obtained from the judgmental evaluation indicate that the Cronbach Alpha value for the screening checklist is very high and the reliability related with the screening is satisfactory. The results of the detailed evaluation are no different. The data related with the external evaluation indicated that the reliability values range from 0.88 to 0.94 . They are within the acceptable range. The results of the internal evaluation show that the reliability values are also very high, the lowest 0.83 and the highest 0.96 . The overall evaluation results are squeezed around "agree" and strongly agree" options and fall above the accepted value. $6 \%$ of the teachers are neutral about the practicality of the materials evaluation system, $46 \%$ of them find it "satisfactory" and $48 \%$ "highly satisfactory". $58 \%$ of the teachers indicated that the effectiveness of the proposed system is "satisfactory" and $42 \%$ "highly satisfactory". In terms of "time-saving" item, 
the results are no different. $3 \%$ of the teachers find the proposed system "unsatisfactory, $9 \%$ neutral; whereas, $52 \%$ find it "satisfactory" and 36\% "highly satisfactory".

Practical Evaluation (Piloting) Results indicate that the proposed system is reliable. The reliability related with the screening checklist is 0.93 , external evaluation 0.87 , and internal evaluation 0.89 . Overall evaluation results show that generally the teachers either go for the "satisfactory" or "highly satisfactory" options. When evaluating the practicality of the proposed system, 3\% of them marked "unsatisfactory", $12 \%$ "neural" options; on the other hand, $42 \%$ of them chose "satisfactory" and 43\% "highly satisfactory. In terms of effectiveness, $49 \%$ of the teachers found the system "satisfactory" and 51\% "highly satisfactory. $43 \%$ of the teachers indicated that the system is "satisfactory" and $51 \%$ "highly satisfactory" with respect to the time-saving quality of the system, while $6 \%$ were remained neutral.

The results comply with the those of Işık and Atmışdört (2010) and AbdelWahab (2013). Işık and Atmışdört (2010) and AbdelWahab (2013) tested the validity and reliability of their checklists and revised them in relation to the data as it was done in this study. Adopting the most appropriate materials in English language is a must, and to do so developing reliable and valid checklists is a must as well. The research and literature about materials development issue are flourishing, yet the checklist development, which is one of the vital means of that process, requires more emphasis.

\section{CONClusion}

First of all, the checklists are the brain child of 156 ELT teachers, not a single expert. They collaborated to create the most sound, practical checklists that can be employed to evaluate ELT materials. This collaboration helped synthesize different perspectives in two-stage evaluation criteria which could be employed by other practitioners in the field.

In addition, the process through which the trainees study ELT materials, materials evaluation and checklist preparation and develop checklist for evaluation is unique in itself. The trainees had no ELT materials evaluation background. First they received theoretical instruction about the topic, got familiar with approaches and discussions and examined checklists. After getting equipped with enough theoretical knowledge they came up with their own and employed it to evaluate ELT materials used in their schools. Some teacher may do the same task without having enough insights into the topic. Thus the training helps trainees have a wider perspective about the topic guides them to make informed decisions while developing their checklists and evaluating their own materials. Hence, the first implication of the study is that raising the awareness of teachers about the topic of interest can be an effective strategy to elicit reliable data about it.

Furthermore, the research indicates that the proposed materials evaluation system and related checklists can be used effectively for materials evaluation. The results about the reliability are found to be high and both the categories and subcategories of the checklists are employed dependably when evaluating materials. Thus, the research helps realize a reliable system for materials evaluation, concise screening checklist and the comprehensive detailed checklist for materials evaluation in language teaching.

Moreover, generally speaking teachers initiate the materials evaluation process directly with the materials evaluation checklist. In other words, it forms the first step of the process. The proposed 3-stage system for materials evaluation presents a unique perspective. First it directs the attention of teachers to context-related factors. It emphasizes the pivotal role of language teaching context in the materials evaluation process. Namely it raises the awareness of English teachers about the role of "the goal of the language program, the context in which it is implemented, the teachers and learners. The overall goal determines the syllabus (knowledge base and language content), the language skills, academic skills, etc. Likewise, the teaching-learning context is to be emphasized as well. It provides invaluable information about the role of English, whether it is a medium of instruction or one of the courses in the syllabus, length and frequency of the English class hours, class size, availability of course materials, technological equipment of classrooms, international trend, national policy, and expectations and attitudes of parents towards English. Furthermore, learner-related factors necessitate special attention. The demographic information about learners, their education background, their needs and interests, their linguistic and cognitive level, their language learning goals affect both affective and cognitive involvement of learners in the language education process. Finally, teacher-related factors need to be taken into consideration. Thus, the research highlights the vital role of context-related factors and reminds that it is the first inescapable step of the materials evaluation checklist development process.

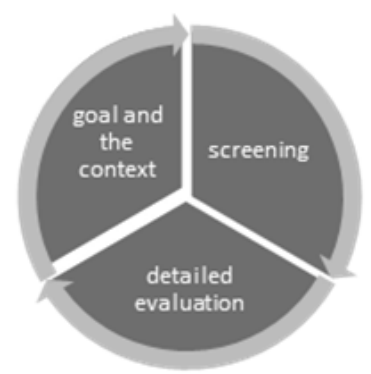

Figure 1. Materials evaluation checklist development process 
The proposed three-stage system is also found to be practical and time saving. Since there are numerous ELT materials on the market, it is not practical to evaluate each and every in detail. Hence, the system and the screening (quick evaluation) checklist speeds up disqualifying the inappropriate ones and saves enough time to focus on the qualified ones in depth.

Additionally, the detailed analysis checklist is composed of two main categories (external and internal) and nineteen subcategories, that is, it offers an extremely comprehensive checklist which pave the way for a thorough evaluation of ELT materials. To the knowledge of the researcher it is the most inclusive one developed so far. In other words, not only does the study propose a new perspective for materials evaluation, but a detailed checklist that may serve the ones who are in search of a thorough tool when evaluating their materials.

Finally, the detailed analysis checklist may appear to be too exhaustive and hard to implement. Because of the screening checklist, only few set of materials are to be evaluated and they deserve enough time and focus to adopt the most appropriate ones. Besides, it can function as a resource for teachers to choose from among to create their own checklists.

\section{ApPEndix A. Materials Evaluation In EFL}

Objectives: This training aims to introduce prospective foreign language teachers to theoretical issues in materials evaluation. Trainees are required to evaluate the ELT materials for a specific group of learners. More specifically, they will

a. gain insights into ELT materials and fundamental concepts and principles about them.

b. gain insights into ELT materials evaluation

Products:

a. Trainees will complete the real-life tasks specified for each week

b. Trainees will come up with a materials evaluation checklist

c. Trainees will evaluate materials

Course Outline

Week 1: Introduction

Week 2: ELT Materials

Nation and Macalister, 2010, Chapter I

Graves, 1996, Chapter 2

Long and Doughty, 2011, Chapter 17

Week 3: ELT Materials

McDonough \& Shaw, 2005, Chapter 4

Byrd, 2002

Tomlinson, 2011, Chapter 1

Week 4: Materials Evaluation

Tomlinson, 2011, Chapter 8

Işık, 2013

Graves, 2000, Chapter 9

Week 5: Materials Evaluation

McDonough \& Shaw, 2005, Chapter 5

Graves, 2000, Chapter 4

Graves, 2000, Chapter 8

Week 6: Materials Evaluation

McDonough \& Shaw, 2005, Chapter 3

Tomlinson, 2011, Introduction

Week 7: Developing Materials Evaluation Checklists

Week 8: Developing Materials Evaluation Checklists

Week 9: Feedback on Checklists

Week 10: Evaluating ELT Materials Using the Developed Checklists

Week 11: Evaluating ELT Materials Using the Developed Checklists

Week 12: Feedback on ELT Materials Evaluation

Appendix B. Materials Evaluation Checklist

I. SCREENING (QUALIFYING EVALUATION) 


\begin{tabular}{|l|l|l|l|l|l|}
\hline & completely unsatisfactory & unsatisfactory & neutral & satisfactory & completely satisfactory \\
\hline Methodology & & & & & \\
\hline Relevance of content & & & & & \\
\hline Publication date & & & & & \\
\hline $\begin{array}{l}\text { Congruence with the aim } \\
\text { of the course }\end{array}$ & & & & & \\
\hline Age level & & & & & \\
\hline Linguistic level & & & & & \\
\hline Time (length of the course) & & & & & \\
\hline Periphery & & & & & \\
\hline Recent, innovative ideas & & & & & \\
\hline Appropriacy to the context & & & & & \\
\hline Software/internet support & & & & & \\
\hline Universality & & & & & \\
\hline Availability & & & & \\
\hline Technological requirements & & & & & \\
\hline $\begin{array}{l}\text { The quality and reliability of } \\
\text { the publisher }\end{array}$ & & & & & \\
\hline Price & $\begin{array}{l}\text { Compact nature of the } \\
\text { learner book. }\end{array}$ & & & & \\
\hline
\end{tabular}

II. DETAILED EVALUATION

a. EXTERNAL EVALUATION 


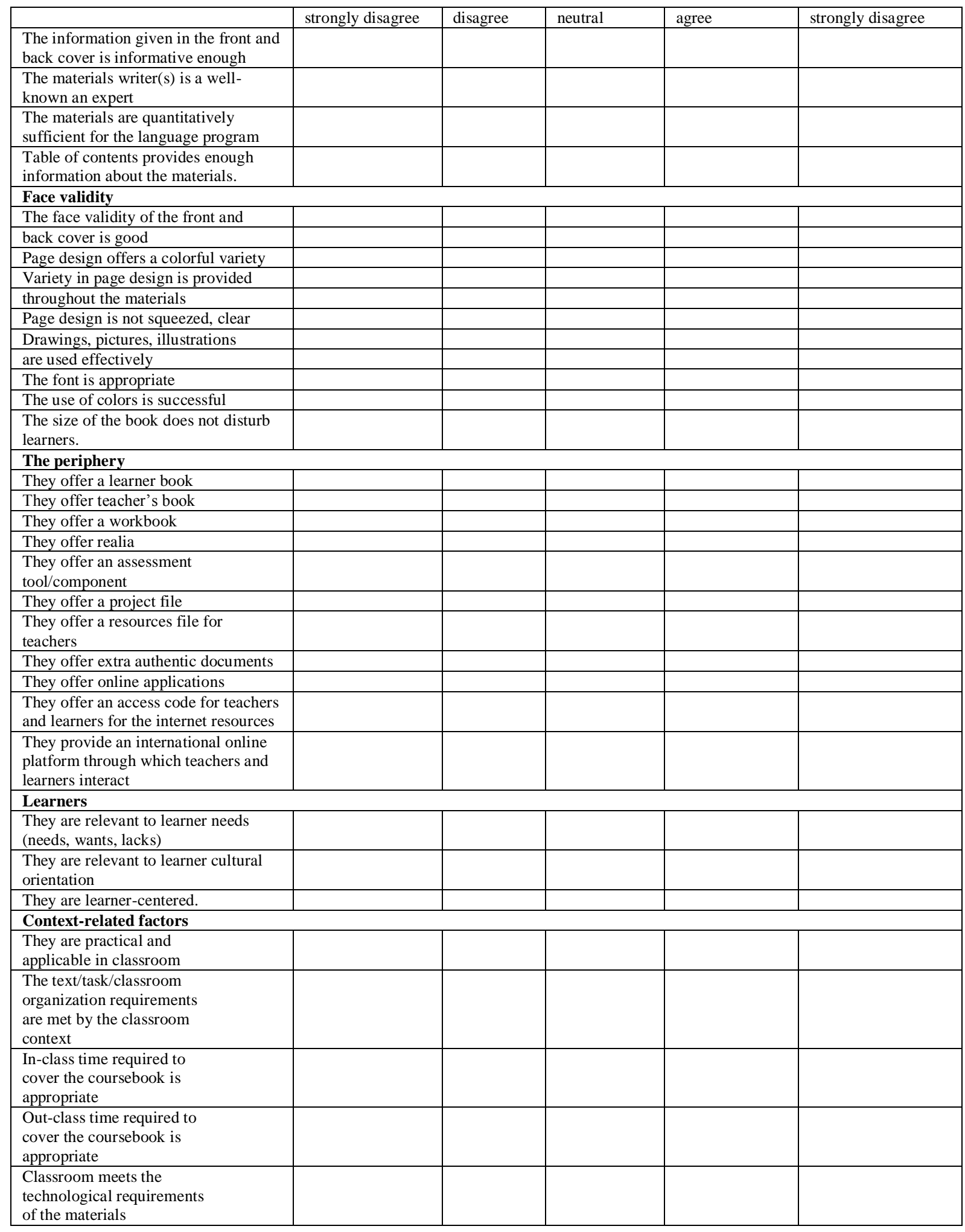

\section{b. Internal Evaluation}

\begin{tabular}{|l|l|l|l|l|l|}
\hline \multicolumn{2}{|l|}{} & strongly disagree & disagree & neutral & agree \\
\hline Approach & & & & \\
\hline $\begin{array}{l}\text { They are based on an up-to-date } \\
\text { language teaching/learning } \\
\text { philosophy }\end{array}$ & & & & & \\
\hline $\begin{array}{l}\text { Adopted language } \\
\text { teaching/learning philosophy is } \\
\text { observed systematically in the } \\
\text { tasks }\end{array}$ & & & & & \\
\hline
\end{tabular}




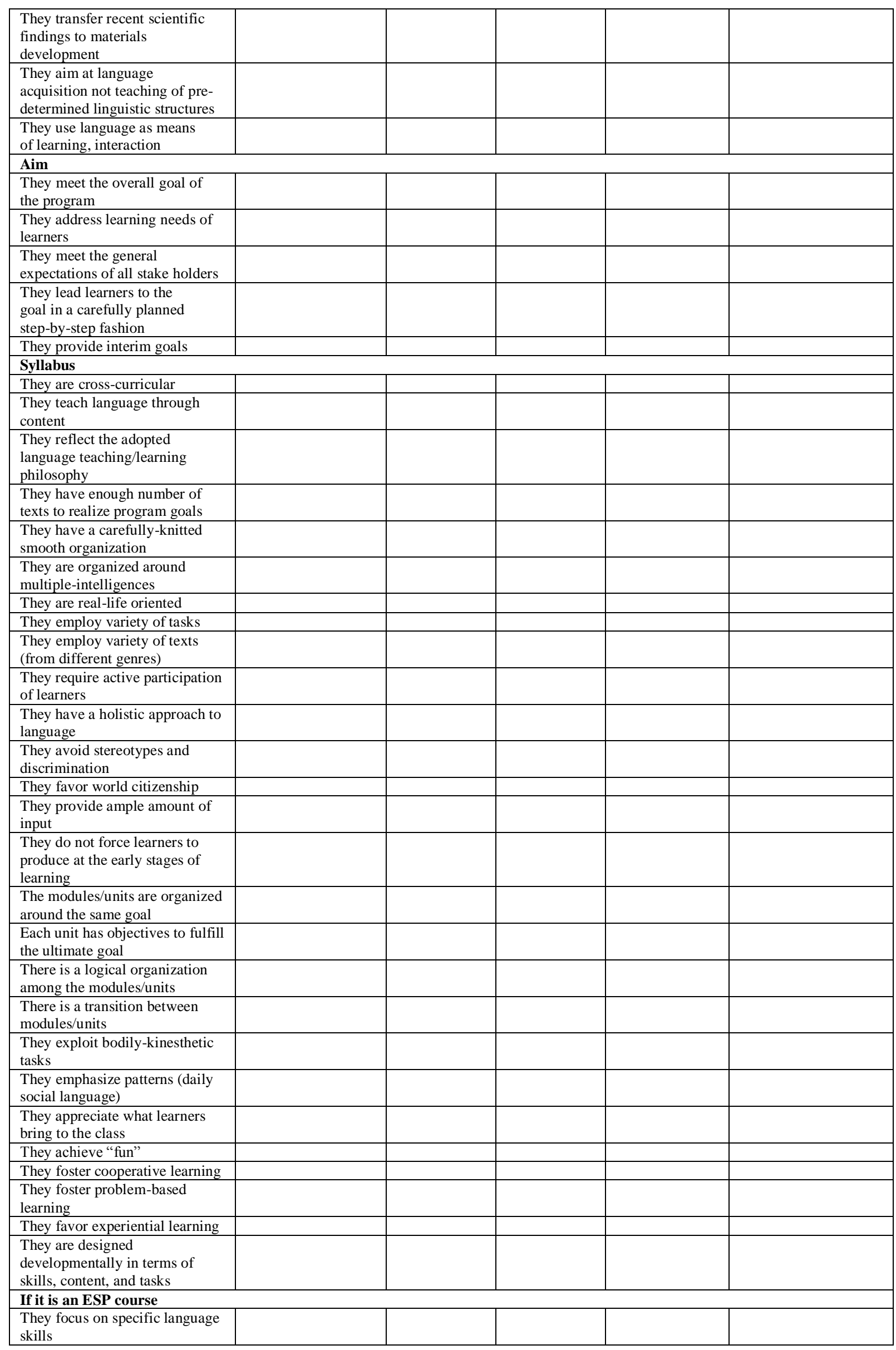




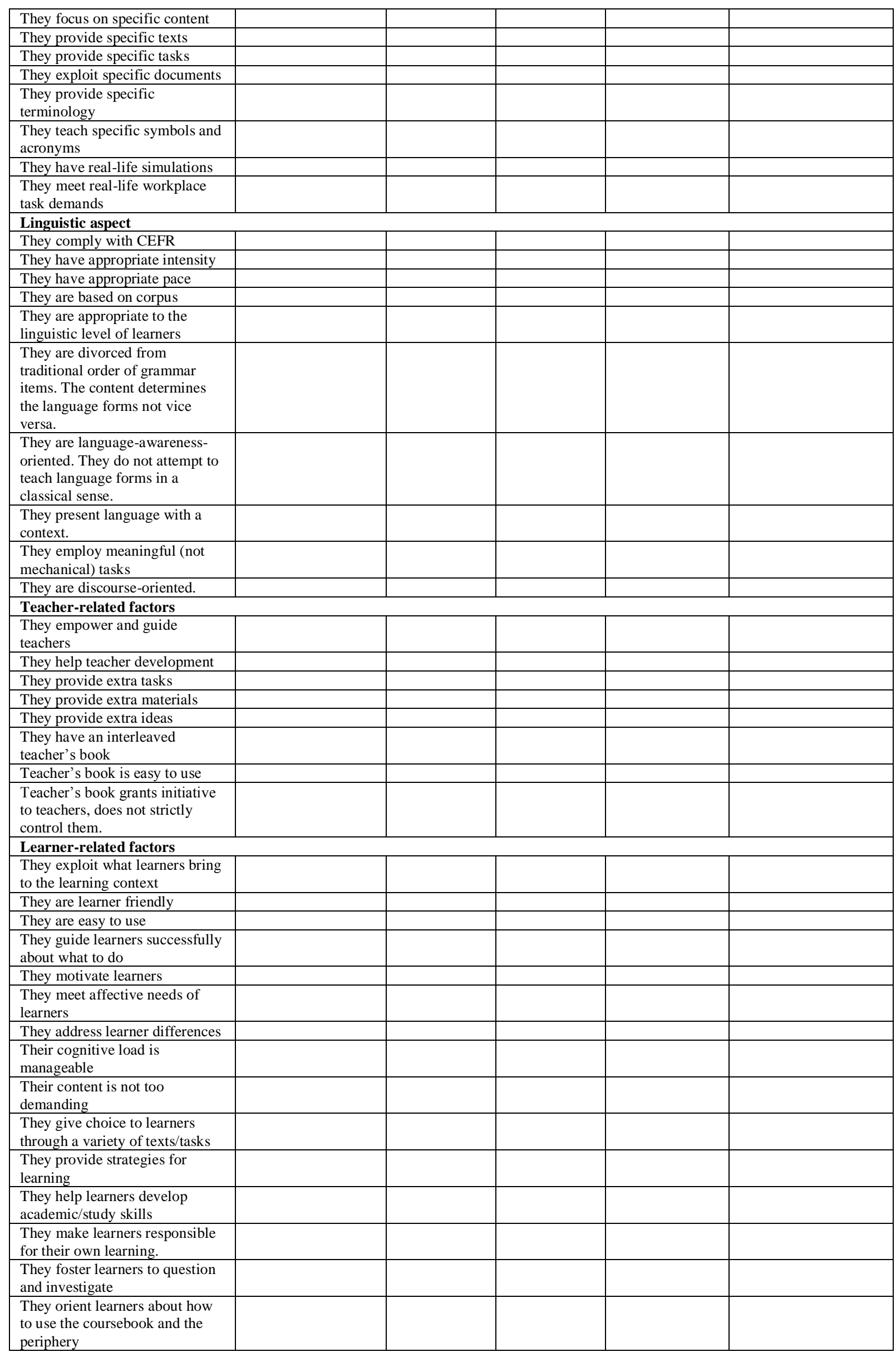




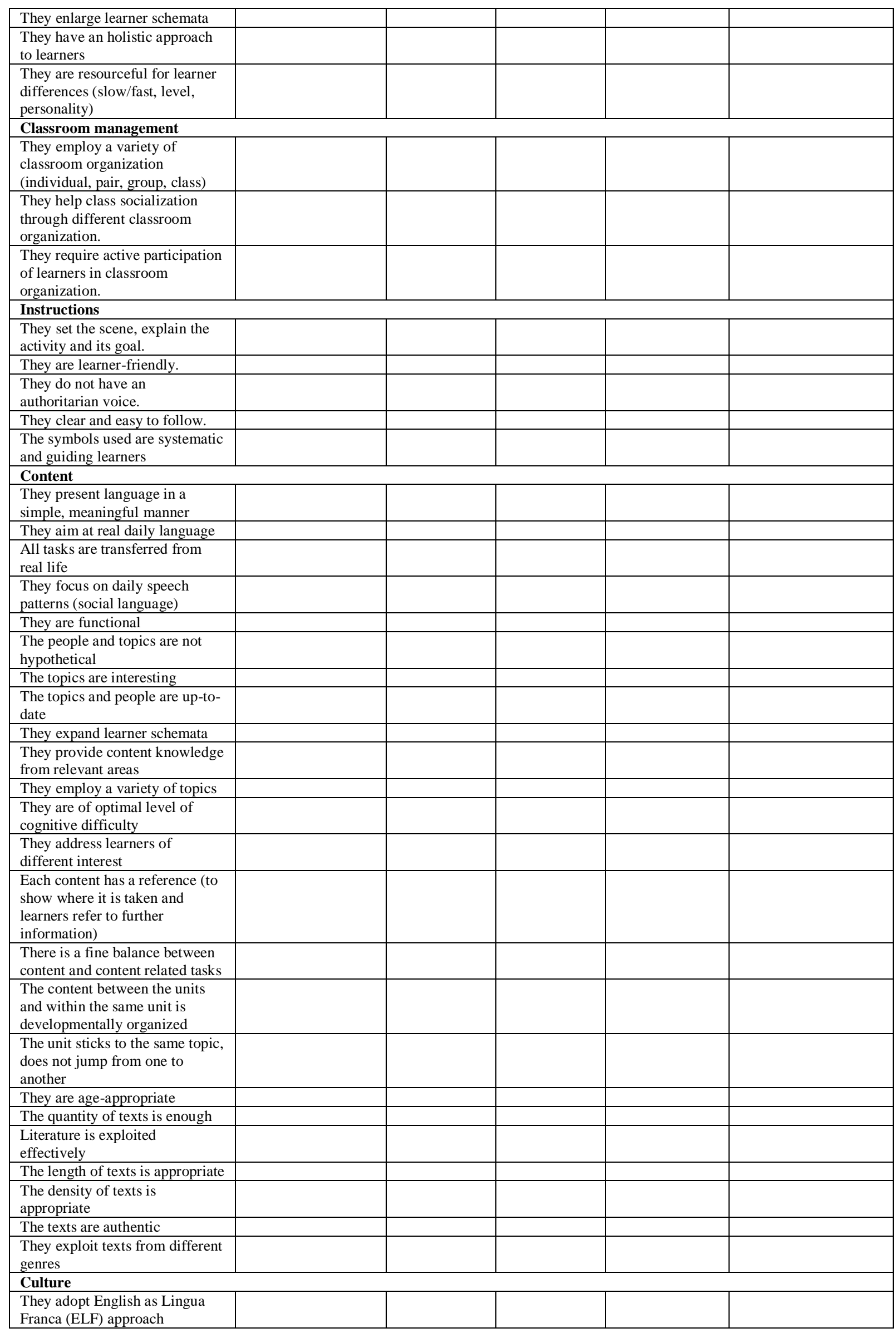




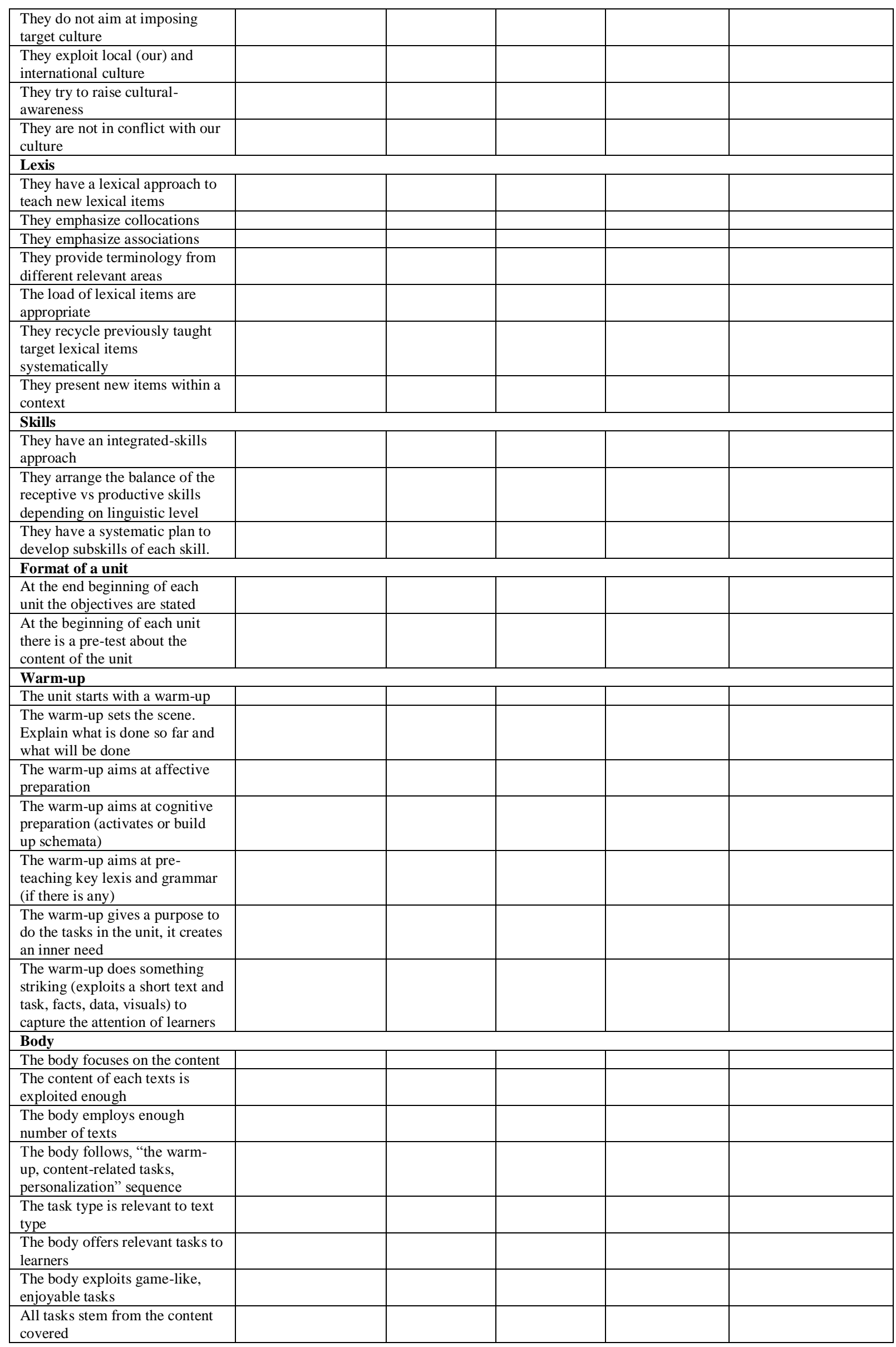




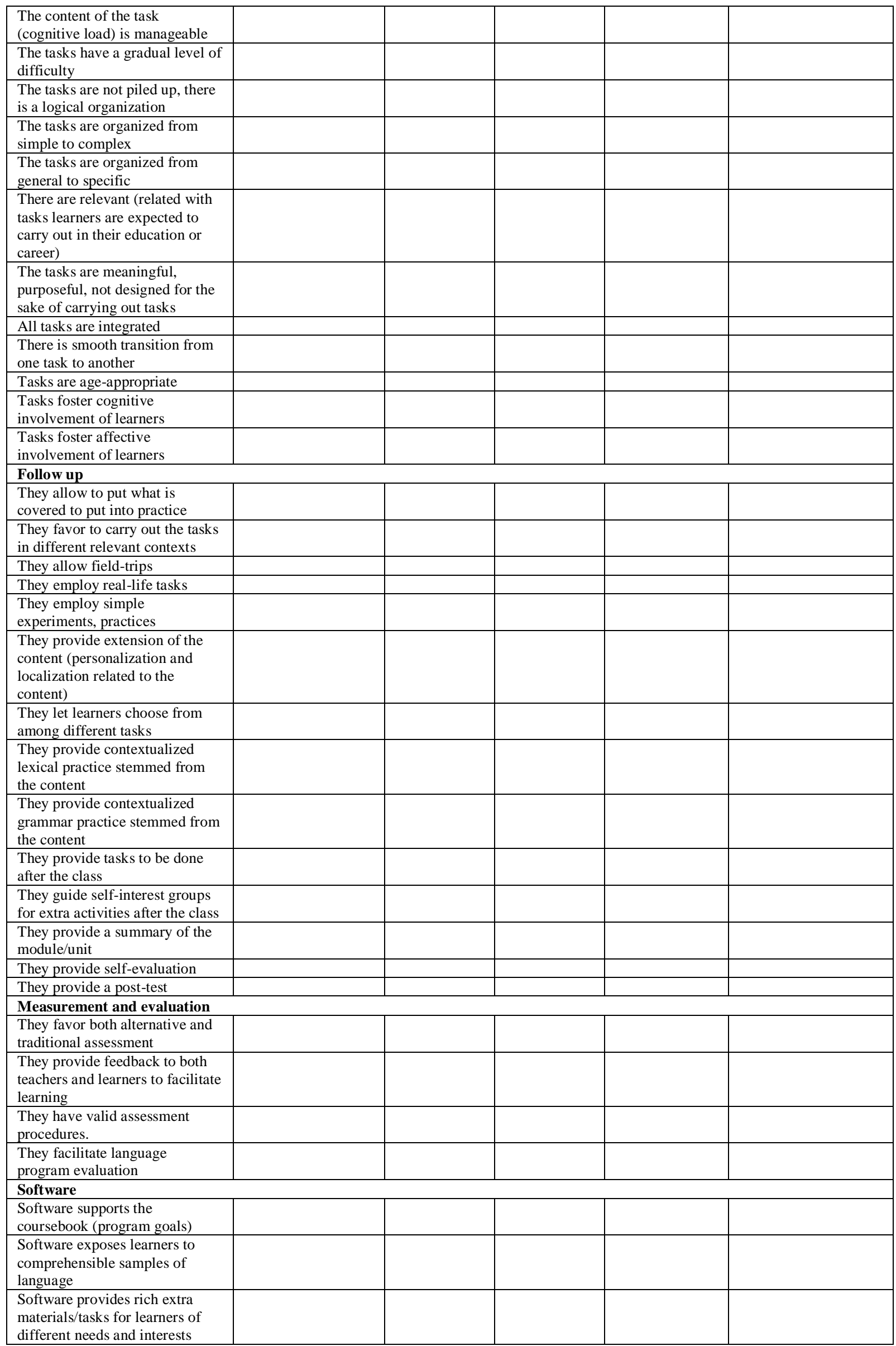




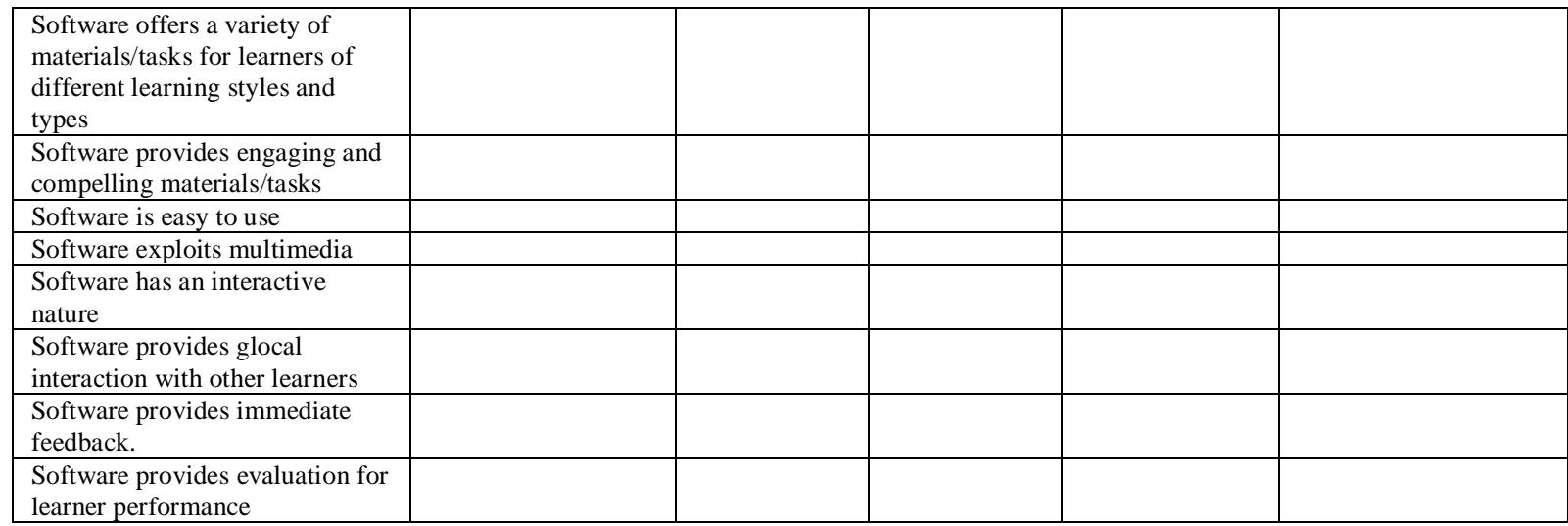

\section{OVERALL EVALUATION}

\begin{tabular}{|l|l|l|l|l|l|}
\hline & $\begin{array}{l}\text { are completely } \\
\text { unsatisfactory }\end{array}$ & $\begin{array}{l}\text { Are } \\
\text { unsatisfactory }\end{array}$ & $\begin{array}{l}\text { need a comprehensive } \\
\text { adaptation }\end{array}$ & $\begin{array}{l}\text { are satisfactory but } \\
\text { need adaptation }\end{array}$ & $\begin{array}{l}\text { are completely satisfactory but need } \\
\text { minor adaptation }\end{array}$ \\
\hline The materials & & & & & \\
\hline
\end{tabular}

\section{REFERENCES}

[1] AbdelWahab, M. M. (2013). Developing an English language textbook evaluative checklist. IOSR Journal of Research \& Method in Education 1.3, 55-70.

[2] Allen, C. (2015). Marriages of convenience? Teachers and coursebooks in the digital age. ELT Journal 69.3, 249-263.

[3] Allehyani, B., Burnapp, D. \& Wilson, J. (2017). A comparison of teaching materials (school textbooks vs authentic materials) from the perspective of English teachers and educational supervisors in Saudi Arabia. International Journal of English Language and Linguistics Research 5.2, 1-14.

[4] Angell, J., DuBravac, S. \& Gonglewski, M. (2008). Thinking Globally, Acting Locally: Selecting Textbooks for College-Level Language Programs. Foreign Language Annals 41.3, 562-573.

[5] Brown, J. D. (1995). The elements of language curriculum. Boston, Massachusetts: Newbury House.

[6] Cunningsworth, A. (1995). Choosing your coursebook. Oxford: Heienemann.

[7] Dubin, F. \& Olshtain, E. (1986). Course design. New York: Cambridge: Cambridge University Press.

[8] Ellis, R. (1997). The empirical evaluation of language teaching materials. ELT Journal 51, 36-42.

[9] Garton, S. \& Graves, K. (2014). Identifying a research agenda for language teaching materials. The Modern Language Journal 98.2, 654-657.

[10] Graves; K. (1996). Teachers as course developers. Cambridge: Cambridge: Cambridge University Press.

[11] Graves, K. (2000). Designing language courses. Cambridge: Cambridge: Cambridge University Press.

[12] Grossman, P. \& Thompson, C. (2008). Learning from curriculum materials: Scaffolds for new teachers? Teaching and Teacher Education, 24, 2014- 2026.

[13] Guyer, E. \& Peterson, P. W. (1988). Language and/or content? Principles and procedures for materials development in an adjunct course. In S. Benesch (ed.), Ending Remediation: Linking ESL and content in higher education. Washington, DC: TESOL Publications, 67-90.

[14] Hargreaves, P. (1989). "DES-IMPL-EVALU-IGN: an evaluator's checklist". In R. K. Johnson (ed.), The second language curriculum. Cambridge: Cambridge University Press, 35-47.

[15] Harmer, J. (2003). The practice of English language teaching. Essex: Longman.

[16] Hart, I. (2003). The outsider's gaze: a learner-centred approach to language-teaching materials. Educational Media International 40.3-4, 287-292.

[17] Harwood, N. (ed.) (2010). Materials in ELT: Theory and practice. Cambridge: Cambridge University Press.

[18] Harwood, N.(ed.) (2014). English language teaching textbooks: Content, consumption, production. Basingstoke: Palgrave Macmillan.

[19] Hirsch, Linda. (1988). Language across the curriculum: a model for ESL students in the content courses In S. Benesch (ed.), Ending Remediation: Linking ESL and content in higher education. Washington, DC: TESOL Publications, 67-90.

[20] Hutchinson, T \& Waters, A. (1987). English for specific purposes. Cambridge: Cambridge University Press.

[21] Iş1k, A. (2011). Language education and ELT materials in Turkey from the path dependence perspective. Hacettepe Üniversitesi Ĕgitim Fakültesi Dergisi 40, 256-266.

[22] Iş1k, A. (2013a). How are ELT materials chosen in high schools? Some suggestions. Hacettepe Üniversitesi Eğitim Fakültesi Dergisi 28, 28-1.

[23] Iş1k, A. (2013b). To what extent does a university level English program meet workplace demands. Education Journal 2. 3 , 98 107.

[24] Işık, A. \& Altmışdört, G. (2010). Yabancı dil öğretiminde malzeme değerlendirme. Uludağ Üniversitesi Eğitim Fakültesi Dergisi 23.1, 221-238.

[25] Johnson, R. K. (ed.) (1989). The second language curriculum. Cambridge: Cambridge University Press.

[26] Kostka, I. \& Bunning, L. (2016). Curriculum design in language teaching. Washington, DC: TESOL Publications. 
[27] Krahnke, K. (1987). Approaches to syllabus design for foreign language teaching. Washington, DC: Center for Applied Linguistics.

[28] Krashen, S. D. (2006). English Fever. Taipeh City: Crane Publishing Company.

[29] Kukulska-Hulme, A., Norris, L. \& Donohue, J. (2015). Mobile pedagogy for English language teaching: A guide for teachers. London: BritishCouncil.

[30] Letter, W. (2000). A Coursebook Evaluation. Birmingham: University of Birmingham Centre for English Language Studies.

[31] Littlejohn, A. \& Windeatt, S. (1989). Beyond language learning: perspectives on materials design. In R. K. Johnson (ed.), The second language curriculum. Cambridge: Cambridge University Press, 155-175.

[32] López-Medina, B. (2016). Developing a CLIL textbook evaluation checklist. LACLIL, 9.1, 159-173. doi:10.5294/laclil.2016.9.1.7.

[33] McDonough, J. \& Shaw, C. (1993). Materials and methods in ELT. Oxford: Oxford University Press.

[34] McDonough, J., Shaw, C. \& Masuhara, H. (2013). Materials and methods in ELT: A teacher's guide (3 ${ }^{\text {rd }}$ ed.). London: Blackwell.

[35] McGrath, I. (2002). Materials evaluation and design for language teaching. Edinburgh: Edinburgh University Press.

[36] McGrath, I. (2006). Teachers' and learners' images for coursebooks. ELT Journal 60. 2, 171-180.

[37] McGrath, I. (2013). Teaching materials and the roles of EFL/ESL teachers: Practice and theory. London: Bloomsbury.

[38] McGrath, I. (2016). Materials evaluation and design for language teaching ( $2^{\text {nd }}$ ed.). Edinburgh: Edinburgh University Press.

[39] Mishan, F. \& Timmis, I. (2015). Materials development for TESOL. Edinburgh: Edinburgh University Press.

[40] O’Neill, R. (1982). Why use textbooks? English Language Teaching Journal 36, 104-111.

[41] Purgoson, K. B. (1991). Planning lesons and units. In M. Celce-Murcia (ed.), Teaching English as a Second or Foreign Language. Boston, Massachusetts: Heinle \& Heinle, 419-431.

[42] Reinders, H., \& Lewis, M. (2006). An evaluative checklist for self-access materials. ELT Journal 60. 3, $272-278$.

[43] Richard-Amato, P. (1988). Making it happen. New York. Longman.

[44] Richards, J. C. (2006). Materials Development and Research-Making the Connection. RELC 37.1, 5-26.

[45] Shave, J. (2010). A Teacher friendly process for evaluating and selecting ESL/EFL coursebooks. The Internet TESL Journal 16, 11.

[46] Sheldon, L. E. (ed.) (1987). ELT textbooks and materials: Problems in evaluation and development. London: Modern English Publications.

[47] Skierso, A. (1991). Planning lessons and units. In M. Celce-Murcia (ed.), Teaching English as a second or foreign language. Boston, Massachusetts: Heinle \& Heinle, 432-453.

[48] Tomlinson, B. (2003). Developing materials for language learning. London: Continuum.

[49] Tomlinson, B. (ed.) (2008). English language teaching materials: a critical review. London: Continuum.

[50] Tomlinson, B. (2010). What do teachers think about EFL coursebooks? Modern English Teacher 19.4, 5-9.

[51] Tomlinson, B. (ed.) (2013). Developing materials for language teaching (2nd ed.). London: Continuum Press.

[52] Tomlinson, B. \& Masuhara, H. (2017). The complete guide to the theory and practice of materials development for language learning. Hohoken, NJ: John Wiley \& Sons.

[53] Willis, D. (2000). Syllabus and materials. Birmingham: The Center for English Language Studies.

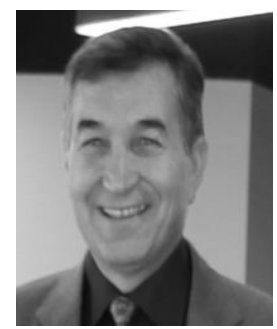

Ali Işı graduated from Bogazici University (Istanbul, Turkey) Education Faculty Foreign Language Education Program in 1989. He completed his MA in 1993 and Ph.D. 1999 at the same university and department. He completed his second MA at Gazi University (Ankara, Turkey) Educational Administration Program in 2006.

Between 1999-2016 he worked as a part-time lecturer at Bogazici University, Middle East Technical University, Hacettepe University, Yeditepe University, and Bogaziçi University consecutively. He is currently the ELT program and materials development advisor and teacher trainer at Istinye University, Istanbul, Turkey. His research interests include language teaching methodology, teacher training, content-based instruction, materials development, measurement and evaluation. 